SVU- International Journal of Veterinary Sciences, 4 (2): 51-59, 2021.

Print ISSN: 2535-1826

\title{
Acute-phase proteins: As a diagnostic tool in pneumonic dromedary Camel
}

\section{Gehad K. Bakhet ${ }^{1}$, Sary K. Abd EIGhaffar ${ }^{2}$, Marwa A. Ahmed ${ }^{3 *}$}

${ }^{1}$ Department of Clinical Pathology, Faculty of veterinary Medicine, Aswan University 81528, Aswan, Egypt, ${ }^{2}$ Department of Pathology and Clinical Pathology, Faculty of Veterinary Medicine, Assiut University 71526, Assiut, Egypt, ${ }^{3}$ Department of Pathology, Faculty of veterinary Medicine, Aswan University 81528, Aswan, Egypt.

\section{Abstract}

Determining the health of animals is important. So, acute-phase proteins consider as important markers of animal health. The acute-phase response is characterized by increased circulating levels of acute-phase proteins released by the liver. In addition, pneumonia is an emerging problem in dromedary camels, with no data available on the diagnostic significance of the markers of acute phase proteins in pneumonic camels. In this report, 44 pneumonic camels were diagnosed by histopathologic analysis of lung tissue from a total of 65 camels. Additionally, five healthy camels were used as control groups. Interstitial pneumonia and fibrinous bronchopneumonia were revealed by histopathology. Blood samples were collected from both groups for determination of haptoglobin, C-reactive protein, and fibrinogen. The result revealed highly significant elevations in haptoglobin, C-reactive protein, and fibrinogen $(1.00 \pm 0.06 \mathrm{~g} / \mathrm{l}$, $13.49 \pm 0.16 \mathrm{mg} / \mathrm{l}$, and $5.47 \pm 0.47 \mathrm{~g} / \mathrm{l}$ respectively) in case of interstitial pneumonia, and also the result revealed highly significant elevations in haptoglobin, C-reactive protein and fibrinogen $(1.04 \pm 0.05 \mathrm{~g} / \mathrm{l}, \quad 13.64 \pm 0.21 \mathrm{mg} / \mathrm{l}$, and5.25 $\pm 0.33 \mathrm{~g} / \mathrm{l}$ respectively) in case of fibrinous bronchopneumonia than in controls. This study concluded that haptoglobin, C-reactive protein, and fibrinogen serve as diagnostic parameters for pneumonia in camels.

Keywords: Acute phase protein, Dromedary camels, Pneumonia.

DOI: 10.21608/svu.2021.61186.1107 Received: February 3, 2021 Accepted: June 4, 2021 Published: June 11, $2021 *$ Corresponding Author: Marwa A. Ahmed E-mail: marwaahmed78@yahoo.com

Citation: Bakhet et al., Acute-phase proteins: As a diagnostic tool in pneumonic dromedary Camel. SVU-IJVS 2021, 4 (2): 51-59.

Copyright: (C) Bakhet et al. This is an open access article distributed under the terms of the creative common attribution license, which permits unrestricted use, distribution and reproduction in any medium provided the original author and source are created.

Competing interest: The authors have declared that no competing interest exists. 


\section{Introduction}

Subclinical infections that have an impact on the health of animals and can remain undetected. Indirectly, sub-clinical infections can be reflected by impaired performance in growth and reproductive efficiency, and may be diagnosed using pathology, microbiology or serology (Elbers et al., 1992; and Tyler and Cullor, 1989). Pneumonia was regarded as a serious problem in Egypt, and subclinical pneumonia infected approximately one in every five camels slaughtered in Cairo abattoirs (Wareth et al., 2014).

Pneumonia is caused by a complex relationship between the environment that creates stress factors, microorganisms, and the host immune response (Bekele et al., 1992; and Ertan, 2006). Various responses of the host to inflammation, infection or trauma are collectively referred to as the acute phase response (Jain et al., 2011).

The acute phase response is induced by protein hormones called cytokines that act as messengers between the local injury site and hepatocytes that synthesis the acute phase protein (Petersen et al., 2004). Positive acute phase protein (APP) functions are considered essential for optimization and trapping of the microorganism and its products and for the activation of complementary system, binding of cellular remnants such as nuclear fractions, neutralising enzymes, scavenging free hemoglobin and radicals and modulating the immune response of the host. APP can be used as a diagnostic tool in many diseases such as the bovine respiratory system, syncytic virus, prostate cancer, bronchopneumonia, multiple myeloma, mastitis, Streptococcus suis infection, malnutrition, or lymph neoplasm. Therefore, acute-phase proteins can provide an alternative method of monitoring animal health (Jain et al., 2011).

\section{Materials and methods}

\section{Animals:}

Sixty-five male camelus dromedaries (4-9 years of age) were used in this study during the period from November 2019 to March 2020 at the Aswan governorate (Daraw slaughterhouse) in Aswan, Egypt. Histopathological was examined on 65 lung samples suspected of gross pulmonary lesions. Also, as a control group, another 5 healthy camels were used. They were clinically healthy and were free of any gross lung tissue lesions.

\section{Blood samples:}

Two blood samples from the pneumonic and control camels were obtained. One sample was taken for plasma fibrinogen level determination in dry and clean tubes containing buffered sodium citrate (3.2\%) (Mackie et al., 2003). The second blood samples were taken in dry plain vacuum centrifuge tubes. The two samples were centrifuged at $3000 \mathrm{rpm}$ for $15 \mathrm{~min}$. and the clear serum or plasma was carefully extracted and stored at $-20^{\circ} \mathrm{C}$ in Eppendorf tubes until biochemical analysis.

\section{Lung specimens:}

Representative samples from the affected lung tissue have been fixed in 10\% neutral buffer formalin. Specimens routinely processed, paraffin enclosed, cut to 4-5-micron thickness. Hematoxylin eosin staining was conducted routinely for general histopathological examination (Bancroft et al., 1996).

\section{Determination of acute phase proteins levels:}

Haptoglobin was automatically determined by using Tina quant @Haptoglobin ver. 2 (HAPT2) kit (Roch 
Diagnostics GmbH, D-68293 Mannheim for USA/US Distribution, Germany).

The C-reactive protein was photometrically determined using the CRPTurbilatex kit (High Top Company 5th Edition, AACC Press, 2000) according to (Okamura et al., 1990).

The level of plasma fibrinogen spectrophotometry was measured using the Immuno Turbidimetry Fibrinogen Kit (Egyptian Company for Biotechnology (S.A.E)).

\section{Statistical analysis:}

The control group was compared with data from the lung affections of the camelus dromedaries. All data were presented as mean \pm standard error of the means (SEM). The $p$ value of $\leq 0.05$ was significant

\section{Results}

Interstitial pneumonia grossly appeared as diffuse elastic texture and on the cut surface, it appeared fleshy (Fig.1 a). Grossly fibrinous bronchopneumonia scattered cranioventral and lung firm in texture and red in colour (Fig.1 b). Inspection of control lung obtained from the Daraw slaughterhouse in Aswan, Egypt revealed no gross lesions (Fig. 1c). Histopathological analysis of 65 specimens of the lung revealed that fibrinous bronchopneumonia reported in 18 camels and interstitial pneumonia was reported in 26 specimens of camel lungs. Histopathological examination of the normal Bactrian camel lung showed in (Fig. 1d) (He et al., 2019).

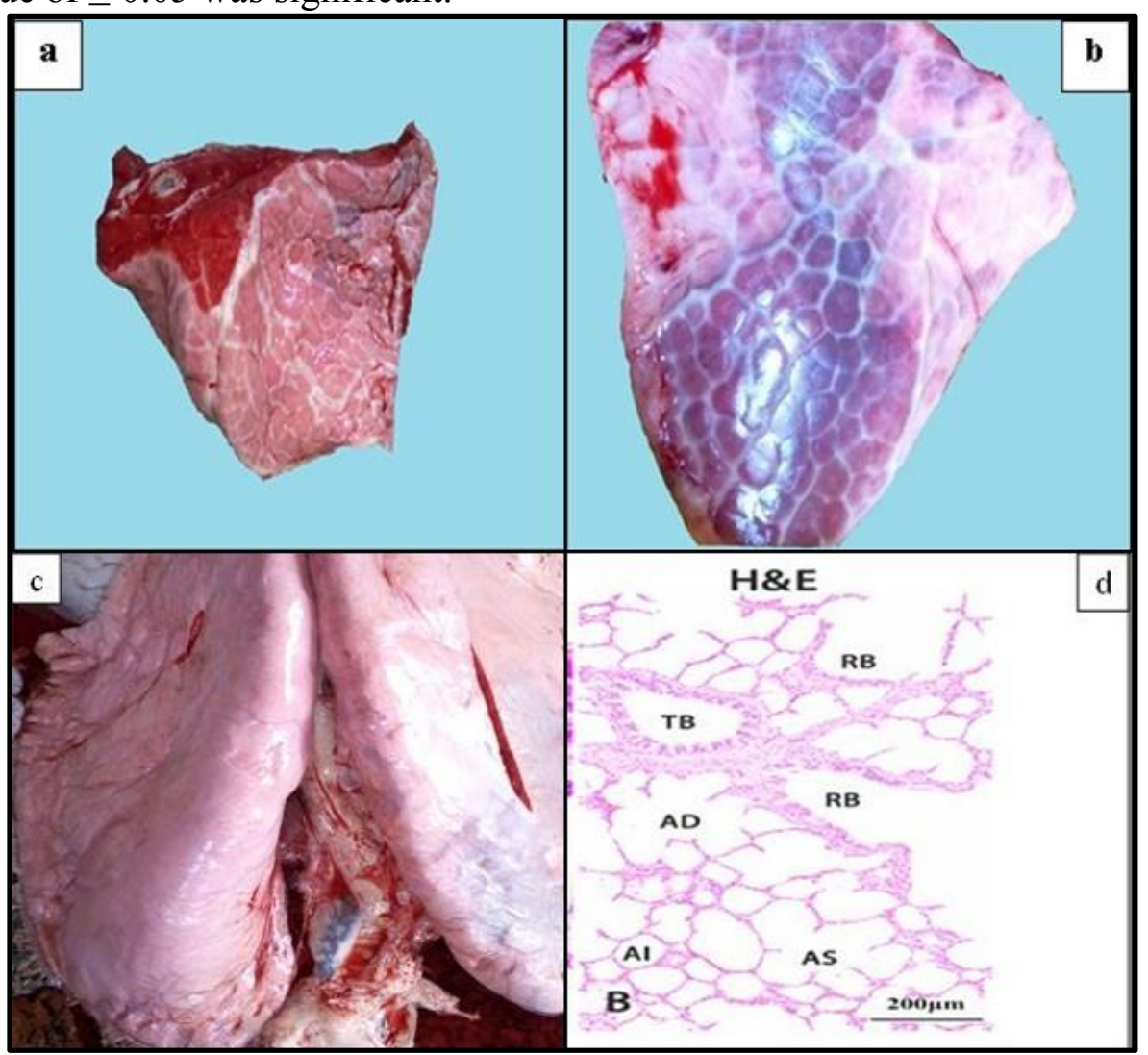

Fig. 1. Lung of camel showing: (a) Interstitial pneumonia, grossly appeared as a diffuse elastic texture, and on the cut surface it appeared fleshy, (b) Fibrinous bronchopneumonia, grossly spread cranioventral and lung firm in texture and red in colour, (c) Control healthy lung tissue obtained from the Daraw slaughterhouse in Aswan, Egypt revealed no gross lesions, and (d) Lung respiratory portion stained with H\&E, showing few alveoli, and a number of alveolar tubes and alveoli sacs. TB: terminal bronchiole; RB: respiratory bronchiole; AD: alveolar ducts; AS: alveolar sacs; AI: alveoli. Original magnification: 100× (B). Images by Wanhong He. 


\section{Broncho-interstitial pneumonia:}

Microscopically, the interalveolar septa were thickened due to type II pneumocyte proliferation, with infiltration of mononuclear inflammatory cells (macrophages and lymphocytes) and fibrin
(Fig. 2a and 2b). Also, adjacent alveoli showed areas of emphysema and atelectasis (Fig. 2a). Bronchiole epithelial cells have been shown to degenerate with peribronchiolar lymphoid cell aggregation (Fig. 2c).

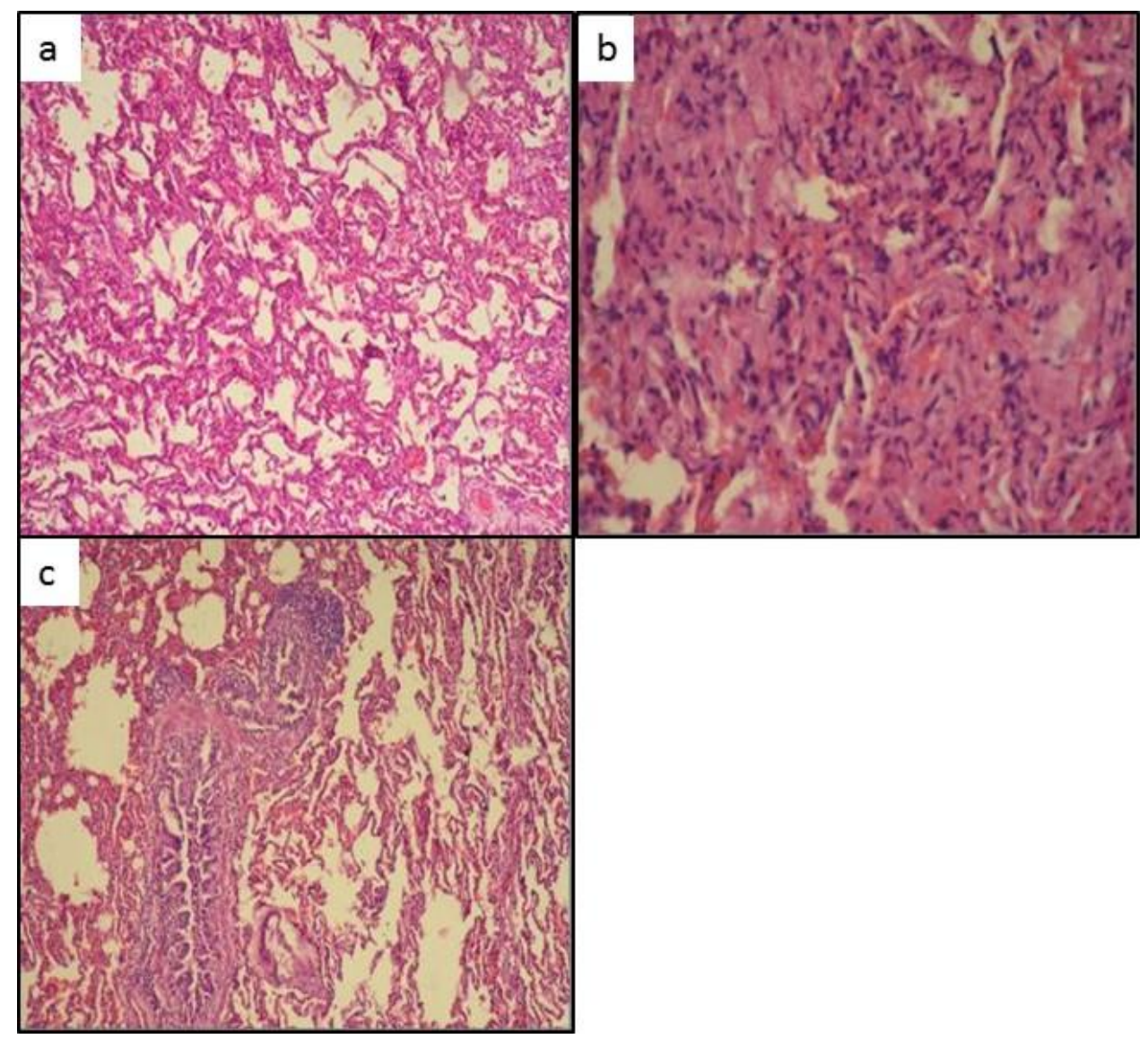

Fig. 2. Lung of camel showing interstitial pneumonia, interalveolar septa thickened due to type II pneumocyte proliferation (a) Infiltration of mononuclear inflammatory cells (macrophages and lymphocytes). Adjacent alveoli showed areas of emphysema and atelectasis (H and E.100x), (b) Infiltration of mononuclear inflammatory cells and fibrin (H and E.400 x), and (c) Bronchiole epithelial cells have been shown to degenerate with peribronchiolar lymphoid cell aggregation (H and E.100x).

\section{Fibrinous bronchopneumonia:}

The alveoli were microscopically packed with fibrinous exudate that appeared as fine threads of acidophilic fibrin (Fig. 3a \& 3b). Red blood cells and leucocytes were admixed with fibrinous exudates in alveoli and other alveoli showed compensatory emphysema (Fig. 3b). Bronchiole lumen is packed with fibrin threads mixed with degenerated epithelium (Fig. 3c).

\section{The effect of pneumonia on blood acute phase proteins:}

There were significant increases in serum haptoglobin, C-reactive protein, and fibrinogen levels in camels with fibrinous bronchopneumonia $(\mathrm{P}<0.01)$ and bronchointerstitial pneumonia $(\mathrm{P}<0.01)$ as shown in Table (1). 


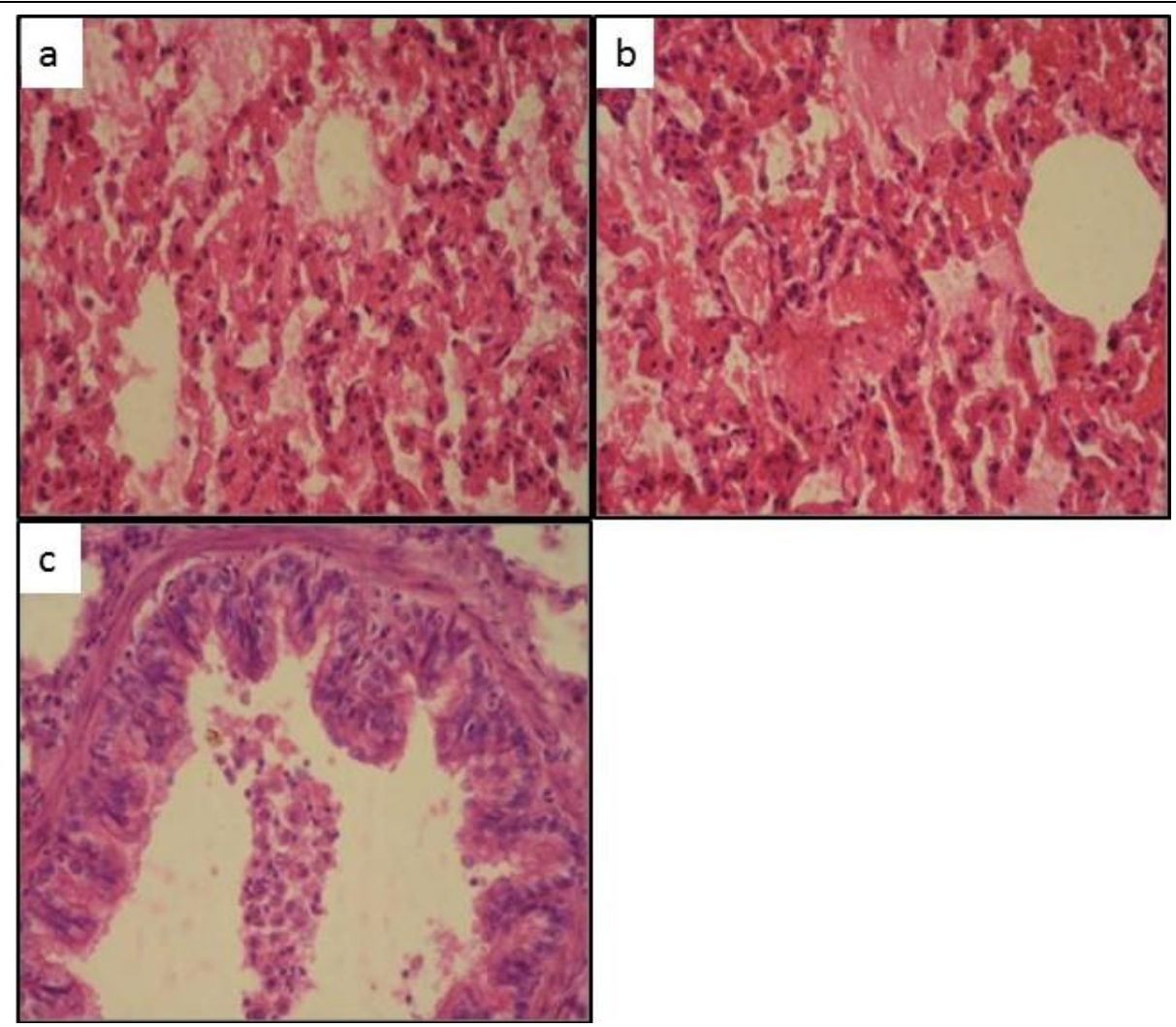

Fig. 3. Lung of camel showing fibrinous bronchopneumonia; alveoli fill with fibrinous exudates that appear as fine acidophilic fibrin threads and proliferation of type II pneumocyte in alveoli (H and E.100x) (a and b), and higher magnification of the bronchiole, note bronchiole lumen filled with fibrin threads mixed with degenerated epithelium (H and E.400x) (c).

Table1: Acute phase proteins in control $(n=5)$ and pneumonic camel $(n=44)$ :

\begin{tabular}{|c|c|c|c|}
\hline Groups (n) & Haptoglobin (g/l) & CRP (mg/l) & Fibrinogen (g/l) \\
\hline Control group (n=5) & $0.35 \pm 0.06$ & $6.27 \pm 0.30$ & $3.94 \pm 0.15$ \\
\hline $\begin{array}{c}\text { Fibrinous broncho- } \\
\text { pneumonia (n=18) }\end{array}$ & $1.04 \pm 0.05^{* *}$ & $13.64 \pm 0.21^{* *}$ & $5.25 \pm 0.33^{* *}$ \\
\hline $\begin{array}{c}\text { Broncho-interstitial } \\
\text { pneumonia (n=26) }\end{array}$ & $1.00 \pm 0.06^{* *}$ & $13.49 \pm 0.16^{* *}$ & $5.47 \pm 0.47^{* *}$ \\
\hline
\end{tabular}

Data are presented as means $\pm \mathrm{SE}(\mathrm{SEM}){ }^{* *}$ highly significant $(\mathrm{p}>0.01)$

\section{Discussion:}

Many apparently healthy camels slaughtered in abattoirs have been recorded to have one or more lung lesions during postmortem inspection (Bekele, 2008, Jenberie et al., 2012). Acute and chronic suppurative, fibrinous, and interstitial bronchopneumonia were the prevalent lesions in dromedary lungs (Awol et al., 2011; Al-Tarazi, 2001). Similar results shown in the present study in which the histopathological analysis of camel lungs with Hematoxylin and Eosin stain revealed fibrinous pneumonia and interstitial pneumonia. 
Respiratory camel infections are a complex multifactorial in nature and are mostly triggered by a mixture of infectious agents such as bacterial, virus, mycoplasma and fungal and other predisposing factors such as poor sanitation; stressful conditions, climate change, unhygienic environment and immunosuppressive state (Abass and Omer, 2005; Taha et al., 2007; Alagaili et al., 2014). This study diagnosed pneumonia in adult camels by using an alteration in acute phase proteins.

Serum haptoglobin concentration was significantly higher $(\mathrm{P}<0.01)$ in camels having fibrinous bronchopneumonia (1.04 \pm 0.05$)$ and broncho-interstitial pneumonia $(1.00 \pm 0.06)$, in comparison with the control group $(0.35 \pm 0.06)$. Haptoglobin is $\alpha 2$-globulin synthesized in the liver (Feldman et al., 2000) and is known to be the major APP in ruminants. Hp could be observed in infected animals prior to the onset of clinical symptoms and its concentration is used as an indication of disease intensity (Godson et al., 1996). Increased levels of $\mathrm{Hp}$ in cattle are interpreted as the result of tissue damage caused by infection or inflammation (Eckersall and Conner, 1988). Similar results in camel calves (El-Deeb, 2015) and in cattle (Eckersall and Conner, 1988; Ganheim et al., 2003). The main function of $\mathrm{Hp}$ is to avoid the loss of iron by the formation of very stable complexes with free hemoglobin in blood (Allison, 1958; Keene and Jandl, 1965; Laurell and Nymann, 1957; Putnam, 1975). Thus, Hp is assumed to have a bacteriostatic impact by limiting the supply of the requisite iron for bacteria (Allison, 1958; Eaton et al., 1982).

The plasma fibrinogen concentration was significantly higher $(\mathrm{P}<0.01)$ in camels having fibrinous bronchopneumonia (5.25 \pm 0.33$)$ and broncho-interstitial pneumonia (5.47 \pm 0.47$)$, in comparison with the control group (3.94 \pm 0.15$)$. Previous research demonstrated higher $\mathrm{Fb}$ levels in camel calves (El-Deeb, 2015) and in infected calves (Nikunen et al., 2007). Fibrinogen is a major glycoprotein. Additionally, fibrinogen-related proteins provide temporary scaffolding for promoting cell adhesion and infiltration, upon which to lay new tissue during reconstruction (Zuliani-Alvarez and Midwood, 2015). Furthermore, Fibrinogen $(\mathrm{Fb})$ is a reliable indicator of inflammation and bacterial infection in bovine and sheep (Nikunen et al., 2007; Gonzalez et al., 2008; Orro et al., 2011).

Serum CRP concentration was significantly higher $(\mathrm{P}<0.01)$ in camels having fibrinous bronchopneumonia $(13.64 \pm 0.21)$ and broncho-interstitial pneumonia $(13.49 \pm 0.16)$ in comparison with the control group (6.27 \pm 0.30$)$. Similar results were recorded by (Tharwat et al., 2013) who reported that a significant increase in CRP levels in pneumonic lamb. CRP binds to many pathogens acting as opsonine. It can also bind to degenerating cells and remnants of cells. CRP also triggers complement by the classical $\mathrm{C} 1 \mathrm{q}$ pathway. CRP is used as a clinical measurement of continuous inflammation (Devaraj et al., 2009).

\section{Conflict of interest statement}

The authors declare that there are no conflicts of interest regarding publication of this article.

\section{Ethical Approval}


The animal experimental protocols were approved by the Animal Care and Use Committee of both Aswan University and Assiut University. All efforts were made to minimize animal suffering and to reduce their number, in accordance with the Egypt National Institutes of Health Guidelines for the Care and Use of Laboratory Animals. for a week before the formal experiment.

\section{References}

Abass B and Omer OH (2005). Review of infectious diseases of the camel. Veterinary Bulletin, 75(8):1-16.

Al-agaili AN, Briese T, Mishra N, Kapoor V, Sameroff S, de Wit E, Munster VJ, Hensley L, Zalmout I, Kapoor, A, Epstein J, Karesh W, Daszak P, Mohammed, O, WI L (2014): Middle East respiratory syndrome coronavirus infection in dromedary camels in Saudi Arabia. MBio, 5(2): 884-814.

Allison AC (1958). The genetical and clinical significance of the haptoglobins. The Royal Society of Medicine, London, England, 51(8): 641-645.

Al-Tarazi YH (2001). The bacteriological and pathological study of pneumonia in the one-humped camel (camelus dromedarius) in Jordan. Revue D Élevage Et De Médicine Véterinary Des Pays Tropicaux, 54(2): 93-97.

Awol N, Ayelet G, Jenberie S, Gelaye E, Sisay T, Nigussie, H (2011). Bacteriological studies on pulmonary lesions of camel (Camelus dromedarius) slaughtered at Addis Ababa abattoir, Ethiopia.
African Journal of Microbiology Research Vol, 5(5), 522-527.

Bancroft TD, Stevens A, Turner DR (1996). Theory and practice of histological technique, 4thEd. Churchill, Livingstone, New York, London, San Francisco, Tokyo.

Bekele ST (2008). Gross and microscopic pulmonary lesions of camels from Eastern Ethiopia. Tropical Animal Health and Production, 40 (1): 2528.

Bekele T, Kasali OB, Woldeab T (1992). Causes of lamb morbidity and mortality in the Ethiopian Highland. Veterinary Research Communications, 16 (6): 415-424.

Bullen JJ, (1981). The significance of iron in infection. Reviews of Infectious Diseases, 3 (6): 1127-1138.

Devaraj S, Singh U, Jialal I (2009). The evolving role of $\mathrm{C}$-reactive protein in atherothrombosis. Clinical Chemistery, 55(2):229-238.

Eaton JW, Brandt P, Mahoney JR, Lee JT (1982). Haptoglobin: A natural bacteriostat. Science, 215 (4533) 691-693.

Eckersall, PD and Conner JG (1988). Bovine and canine acute phase proteins. Veterinary Research Communications, 12(2-3):169-178.

Elbers ARW, Tielen MJM, Cromwijk WAJ, Hunneman WA (1992). Varition in seropositivity for some respiratory disease agents in finishing pigs: epidemiological studies on some health parameters and farm and management 
conditions in the herds. Veterinary Quarterly, 14(1): 8-13.

El-Deeb WM (2015). Acute phase response and oxidative stress parameters in pneumonic camel calves (camelus dromedarius). Bulgarian Journal of Veterinary Medicine, 18 (3): 258269.

Ertan ORUC (2006). The pathologic and bacteriologic comparison of pneumonia in lambs. Turkish Journal of Veterinary and Animal Sciences 30(6):593-599.

Feldman BF, Zinkl JG, Jain NC (2000). Schalm's Veterinary Hematology. 5th edn, Blackwell, Ames, Iowa, pp. 1344.

Ganheim C, Hulten C, Carlsson U, Kindahl H, Niskanen R, Walter, KP (2003). The acute phase response in calves experimentally infected with bovine viral diarrhoea virus and/or Mannheimia haemolytica. Journal of Veterinary Medicine, Series B, 50 (4): 183-190.

Godson DL, Campos M, Attah-Poku SK, Redmond MJ, Cordeiro DM, Sethid MS, Harlanda RJ, Babiuka LA (1996). Serum haptoglobin as an indicator of the acute phase response in bovine respiratory disease. Veterinary Immunology and Immunopathology, 51(3-4): 277292.

Gonzalez FHD, Tecles F, MartınezSubiela S, Tvarijonaviciute A, Soler L, Cerón JJ ( 2008). Acute phase protein response in goats. Journal of Veterinary Diagnostic Investigation, 20(5): 580-584.
He W, Zhang W, Cheng C, Li J, Wu X, Li M, Chen Z, Wang W (2019). The distributive and structural characteristics of bronchusassociated lymphoid tissue (BALT) in Bactrian camels (Camelus bactrianus). Peer J 7, e6571: 1-17.

Jain S, Gautam V, Naseem S (2011). Acutephase proteins: As diagnostic tool. Journal of Pharmacy and Bioallied Sciences, 3 (1): 118-127.

Jenberie S, Awol N, Ayelet G, Gelaye E, Negussie H, Abie G (2012). Gross and histopathological studies on pulmonary lesions of camel (Camelus dromedarius) slaughtered at Addis Ababa abattoir, Ethiopia. Tropical Animal Health and Production, 44(4): 849-854.

Keene WR and Jandl JH (1965). The sites of hemoglobin Catabolism. Blood, 26 (6): 705-719.

Laurell CB and Nyman M (1957). Studies on the serum haptoglobin level in hemoglobinemiae and its influence on renal excretion of hemoglobin. Blood, 12 (6): 493-506.

Mackie, IJ, Kitchen S, Machin SJ, Lowe GD (2003). Haemostasis and thrombosis task force of the British committee for standard in hematology: Guidelines on fibrinogen assays. British Journal of Haematology, 121(3): 396-404.

Nikunen S, Hartel H, OrroT, Neuvonen, E, Tanskanen R , Kivelä, S-L, Sankari S, Aho, P, Pyörälä S, Saloniemi H, Soveri T (2007). Association of bovine respiratory disease with clinical status and acute phase 
proteins in calves. Comparative Immunology, Microbiology \& Infectious Diseases, 30 (3): 143151.

Okamura, JM, Miyagi JM, Terada K, Hokama Y (1990). Potential clinical applications of C-reactive protein. Journal of Clincal Labortory Analysis, 4(3):231-235.

Orro T, Pohjanvirta T, Rikula U, Huovilainen A, Alasuutari S, Sihvonen L, Pelkonen S, Soveri T (2011). Acute phase protein changes in calves during an outbreak of respiratory disease caused by bovine respiratory syncytial virus. Comparative Immunology, Microbiology \&Infectious Diseases, 34(1): 23-29.

Petersen HH, Nielsen JP, Heegaardb PMH (2004). Application of acute phase protein measurements in veterinary clinical chemistry. Veterinary Research, 35(2): 163-187.

Putnam FW (1975). Haptoglobin In: Putnam FW, editor the plasma proteins, structures, functions and genetic control. New York. Academic Press, 2:1-50

Taha K, Shlaby A, Sami MB, Deeb S (2007). Pathological studies on the association of pneumonia and

kidney affection in camels (Camelus dromedarius). Egypt. Journal of Pathology and Clininical Pathpathology, 20(1): 235-262.

Tharwat IA, Alkabbany MF, Abeer MA, (2013). Bacteriological and Pathological studies on pneumonia in lambs with special references to inflammatory markers. Zagazig Veterinary Journal, 41 (2): 76-87.

Tyler JW and Cullor JS (1989). Titers, tests and truisms: Rational interpretation of diagnostic serologic testing. Journal of the American Veterinary Medical Associations, 194 (11): 1550-1558.

Wareth G, Murugaiyan J, Dalia F, Khater DF, Moustafa SA( 2014). Subclinical pulmonary pathogenic infection in camels slaughtered in Cairo, Egypt. Journal of Infection in Devoloping Countries, 8(7): 909913.

Zuliani-Alvarez L and Midwood KS (2015). Fibrinogen-related proteins in tissue repair: How a unique domain with a common structure control diverse aspects of wound healing. Advances in Wound Care, 4 (5): 273-285. 